gramme for post-war scientific research. The report is reprinted as a handsome brochure together with the reports of the four specialist committees---the Medical Advisory Committee, the Committee on Science and the Public Welfare, the Committee on Discovery and Development of Scientific Talent, and the Committee on Publication of Scientific Information. Dr. Bush himself contributes a foreword, and the whole is now provided with an index, which enhances its value to all concerned with the relations between science and government and education. An admirable introduction by Dr. A. T. Waterman, director of the National science Foundation, summarizes the extent to which the recommendations of the report have been implemented during the past fifteen years and points to some of the problems which still await solution. The reprint is to be welcomed as making readily available to a further generation of those responsible for the ordering of the national effort in scientific research and development in Britain, no less than in the United States, the clear and creative thinking of a distinguished group of experienced and responsible scientists. The report is obtainable from the National Science Foundation, Washington, D.C.

\section{IGY Bulletin}

WiтH the July issue (Number 37, 1960) the IGY Bulletin entered its fourth year of publication. The original aim of the Bulletin was primarily to keep participating scientists informed of progress in the United States programme, and to a limited extent, in programmes of other countries, but a large number of students, teachers and other interested persons expressed interest in the work and near the end of its first year of publication the Bulletin was made available on a subscription basis. The observational phase of the International Geophysical Year ended on December 31,1958 , but the programmes were continued during 1959 and have been succeeded by world-wide geophysics and space-science programmes. The great body of accumulated data still requires analysis, and the $I G Y$ Bulletin is being continued in order to complete the record of reports of the International Geophysical Year and the related studies, and of investigations in geophysics and space research as they bocome available. The Bulletin is also re-printed in the Transactions of the American Geophysical Union.

\section{The Weizmann Institute of Science}

THE annual report for 1958-59 of the Weizmann Institute of Science records a steady increase in support, and the president, Abba Eban, records the intention in 1960 to explore the potentialities of science and technology in the development of new independent States, especially in Asia and Africa (Pp. 108. Rehovoth, Israel : Weizmann Institute of Science, 1960). Of the scientific activities, Prof. A. M. J. Schmidt, chairman of the scientific committee, refers to the expansion of the two-year-old programme of virological research in the Department of Experimental Biology ; the exploitation by nuclear physicists of the possibilities offered by the Van de Graaff accelerator for designing experiments along new lines; the growing demands on the electronic computer Weizac, to growing international interest in the work of the Biophysies Department; and to the pooling of resources by scientists in the Departments of Biochemistry, Biophysies, Experimental Biology and X-Ray Crystallography for a major collaborative effort in molecular biology. Much thought has been given to the founding and work of Yeda, a research and development corporation, to foster the commercial exploitation of discoveries made in the Institute's laboratories and to provide stimulus by closer contact with the scientific problems of industry. At the Graduate School in the Natural Sciences there are now seventy-five research students, and eighteen obtained their Ph.D. degree during the year. Besides brief accounts of some of the investigations in progress in the various Departments, the report includes a list of scientific, administrative and technical staff. A list of papers published by members of the scientific staff, 1958-59, has been issued simultaneously with this annual report, but independently, and the library has also issued a definitive edition of "Serial Holdings of the Weizmann Institute of Science, 1959".

\section{An Investigation on Mounting Boards}

RECENTLY a report concerning mounting boards has been made by the Fibre Research Institute of the Central Netherlands Organization for Applied Scientific Research at Delft at the request of the Dutch Museums Association. The Museums Journal for August, 1960, contains extensive notes from this report. In the past little has been known about the precise properties required in this type of board and it was considered useful to investigate various widely differing boards and so provide a basis for a set of standards. The properties which mounting boards should possess were considered under various headings and include flatness, colour, opacity, resistance to light, polluted air and micro-organisms, durability, strength, bulk and stiffness. The report makes some definite recommendations concerning the factors on which information was sought and the paper quoted gives these in some detail. It is interesting to note, for example, that the board should be free of ground wood and be manufactured from good-quality bleached pulp. For this, unused rags and soft-wood sulphate pulp bleached by the chlorine dioxide process are acceptable.

\section{Bibliography of British Archæology}

The Council for British Archæology has produced "A Booklist", slim and paper backed, with 41 pages of book titles and with very occasional explanatory notes as to their contents (Pp. 43. (London : Council for British Archæology, 10 Bolton Gardens, S.W.5, 1960.) $5 s .6 d$.). These are divided into sections dealing with: (1) Periods-from the Palæolithic to the Industrial Revolution; (2) Regional books, covering England, Scotland and Wales; (3) Books for children, and a short section of regional studies of a more elementary nature. The list is intended to help those of all ages who wish to take an intelligent interest in the past of Great Britain whether it be the Stone Ages, the Roman Period, the Gothic architecture, the domestic building or the furniture, clothes, crafts, silver or ceramics which interest them most. It is not stated who is responsible for the selection of titles.

\section{Sinhalese Sports and Pastimes}

AтнLetics have always been popular, but there has often been held an erroneous idea that activities such as wrestling and the like were mainly sports indulged in by peoples living in the more western and northerly parts of Europe. Dr. P. E. P. Derariyagala, director of the National Museums in Ceylon, has now shown in his fascinating volume "Some 